\title{
NON-CHRISTIAN MASTERS IN MISSION SCHOOLS
}

\author{
By The Rev. Canon E. H. M. Waller
}

Tre fact that in mission schools a considerable proportion of the teaching staff consists of non-Christians frequently provokes criticism and causes concern to supporters of the work at home. The proportion varies in different provinces. In North India, where education is not so advanced and Christianity has not had time to progress as much as in the south, the proportion is frequently high. In Bengal and South India things are better; while in Ceylon the whole staff is generally Christian. But in the north we are still a long way from this standard. It has to be admitted that in many mission schools only one-half or a third or sometimes even a smaller proportion of the masters are Christians. Before passing judgment, however, it is desirable that an effort should be made to understand the circumstances which give rise to this state of affairs. It is not likely that missionaries of all societies and countries would agree in this policy unless they believed it to be the best, or unless they had no alternative. We do not believe it to be the best policy ; we deplore the necessity for the employment of nonChristians, but we do not for a moment admit that our institutions are useless from an evangelistic point of view.

It is the old question of expansion versus silence. Take a given town. If there were no mission school, there would be a government school with non-Christian masters and purely secular teaching, undermining Hinduism and Mohammedanism, breaking down old standards of morality and old ideas of right and wrong, and substituting materialism; or there might be a theosophical school to bolster up Hinduism, or a frankly Hindu or Mohammedan institution, or-worst of all-a non-religious school under a local committee of non-Christians with no ideals at all except the passing of examinations. 
These are the alternatives. Shall our work be organized on the principle of some good for the greatest number, or the ideal, if we can secure it, for a few?

Or again, the missionary sees the alternatives thus: If $I$ give up my school, I can preach daily in the villages and in the streets. I shall get a changing audience, frequently composed of loafers and idlers, with a rare visit from a man of education and little chance of following up the work. If I keep my school, I shall have the same audience year after year. They will be a picked audience of educated boys. I shall have them for perhaps ten years of their life at the most formative period. Not only shall $I$ preach to them daily, but I shall be able to make friends with them in the playingfields and perhaps the boarding-house. As their schoolmaster I shall have a lifelong influence over them and a ready entrance into their homes at all times. As their teacher my position will be assured. Even in the streets I shall be listened to quietly, for I shall be known to some at least as " my son's teacher."

What will he choose? What will any man in his senses choose? Will he give up the great opportunity because there will be others in the school who may use arguments against his teaching? Why, if he preaches in the bazaars and villages, will the pandits and maulvies and friends remain silent? Will an inquirer be better prepared to meet the arguments which must come if he has heard the Gospel once or twice in a crowded audience or if he has been regularly instructed in the Bible in the quiet of the classroom? Will he be more receptive because he has been educated in a wholly secular school, which has disturbed many of his old traditions and given him no religious training at all in their place ?

No: admitting that the conditions are not absolutely perfect, that in the mission school, as in all the rest of the world, there are tares mingled with the wheat, and that the taught and the teacher will alike be tested in the furnace of the world, the chances of doing good to a greater number of people are far brighter, if we accept the mission school.

If any one were to take the trouble to examine the facts he would find that there are more Christian masters in mission schools now than ever before. The great Dr. Duff had to work with practically an entirely non-Christian staff. If there are few educated Christians now who are capable of teaching in colleges and high schools, there were fewer then; and yet we owe the majority of 
our schools to the foresight and faith of these old missionaries. Schools have individually more Christian masters than they had in their early days; and the general influence of Christianity, if measured by the aggregate of Christian teaching in any one province, is, of course, far greater than it ever was before.

It is partly a question of the supply. In the north of India, at any rate, the Christian population is not yet large enough to supply masters sufficiently trained and educated to staff all the institutions throughout. It was calculated a few years ago that in one province one in seven of the adherents of one mission was engaged in mission work. This proportion is extraordinarily high ; in fact, economically it is dangerous. Surely it is far more healthy for the community that the educated young men should find employment and make their influence felt in government offices and schools, in trade and on the railways, and in the thousand and one departments of life, where they can set a Christian example. Therefore, even supposing that all educated Christians were enlisted as masters in mission schools, the result would not be for the good of India as a whole, and certainly not for the good of the Church. It would mean that their influence in ordinary life would be largely lost. It would mean that all the educated members of the community would be in the employ of the mission, and such a state of things would sap the life of the Church.

As a matter of fact mission service is not popular with the Indian Christian. This is the case both in evangelistic and in educational work. If you can persuade Indians to give you their own reasons, they will tell you that " the worker is too much at the mercy of one man, and that man is a foreigner. He demands western ideas and methods, which are unsuited to India The employer is transferred and another, perhaps a young man with all a young man's severity, takes his place, and there is a clean sweep and no appeal. The pay is low and there is no pension. There is little chance of rising to the top except by special favour of the missionary." These are some of the arguments which are put to the candidate for mission employ by his friends. Of course they are exaggerated, and circumstances vary in different places, but there is an uncomfortable substratum of truth underlying them and this estimate of mission service is sufficiently widespread to deter him.

There is also a healthy sense of independence in the mind of the 
young Christian. Why should he be dependent on the mission for his income when he might earn money otherwise and help his Church ?

The financial question is another aspect of the case. It is not paramount, and it is a reproach to the Churches at home that it should have to be mentioned, but it cannot be ignored. The standard of living among Christians is higher than that ruling among non-Christians. This is due partly to the joint family system of the Hindus, which is not followed by the Christians, and partly to the adoption of western standards by the Christians. There is no need to enter into all the reasons for this. It is a well-known fact and it cannot be ignored. It cannot be altered, certainly not by foreigners ; indeed it is not at all certain that we should desire to alter it. There are not wanting signs that the Christian standard of to-day will be India's standard to-morrow. Be that as it may, the fact has to be faced that Christian masters command higher salaries than non-Christians, and there is many a mission school which with a mixed staff is just paying its way, but with a wholly Christian staff would need to revise its budget and discover fresh sources of income. This difficulty may be merged in a greater one as the pay of the whole teaching profession goes up. It is at present scandalously low, and the Government has recognized that this is a reform which must be taken in hand at once and a beginning has been made. The difference between the pay of a Christian and of a non-Christian may tend to disappear, though it is not probable that this will be so for some time to come. None the less the Church must be prepared to spend more money on education, if our institutions are not to fall behind in the race for efficiency and are not to have the additional difficulty of lack of funds to hinder the employment of more Christians.

Here is the monthly budget of an exceptionally favoured school employing some six Christian masters out of a staff of thirty :-

INCOME.

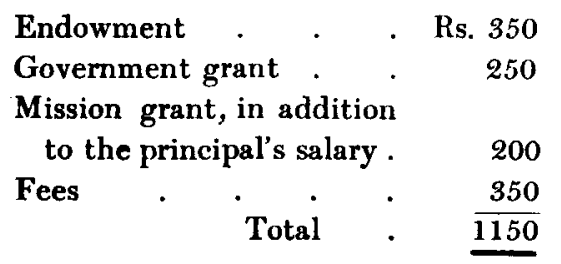

Expenditure.

$$
\begin{aligned}
& \text { Staff . . . . Rs. } 700 \\
& \text { Upkeep . . . } 100 \\
& \text { Rent and taxes . . } 50 \\
& \text { Total }{ }^{\text {Teaving a balance for repairs, }} \\
& \text { furniture, and extension. }
\end{aligned}
$$


The balance saved for a year or two was used for fitting up a science and commercial department, both of which had become necessary, and for much-needed additional furniture. When this was done three or four Christian masters were added to the staff.

Two years afterwards the budget for a month read as follows :-
INCOME . . . Rs. 1200
(an increase in fees accounting for this).

Expenditure $\left\{\begin{array}{lr}\text { Staff . } & \text { Rs. } 1020 \\ \begin{array}{c}\text { Upkeep, rent, } \\ \text { etc. }\end{array} & .\end{array}\right.$

leaving a narrow margin for repairs, renewal of furniture, etc.

The position of the school was of course secure, though only because of the large endowment it was fortunate enough to possess. But the figures will show what the position of schools without such endowments is, and what a serious problem finance is. Consider the significance of the fact that in that place a non-Christian B.A. could be obtained for Rs. 45 a month and a Christian who had only passed the first Arts examination (two years in college instead of four) could not easily be got for Rs. 45. It will readily appear that any large enlistment of Christian masters under the present conditions must seriously affect the financial stability of schools.

It may be asked why money must be raised at home. The fact is that apart from this source there are only government grants, given on the secular efficiency of the school, and fees.

The acceptance of the government grant raises a difficult general question concerning the scope and object of mission work, into which we need not enter now. A practical question is that it gives the Government a very real voice in the management of our schools and colleges, and, indirectly, in the appointment of the staff. Again, the acceptance of a grant for secular work, which is tested throughout by examinations, always has a tendency to make the secular work and examination loom most largely in the teacher's mind, instead of his teaching being first and foremost a contribution to the wider life of the pupil. It is for this reason that we find directors of public instruction sighing for teachers who have a vocation. But apart from all these questions, the increasing expenditure required to keep up the increasing standard of efficiency will not be met by any probable increase of the government grant; and it is quite certain that the fact that we have to pay larger salaries to Christian masters than to non-Christians (who are from the secular 
point of view equally efficient) will not constitute a claim in the eyes of Government to larger grants.

The other source of income is fees. These again are determined by the government standard. They may not be lower than a fixed minimum. They can not often be higher than the rates ruling at government schools. The superiority of mission schools is not so marked in the eyes of all Hindu and Mohammedan parents that they are willing to pay for the privilege of sending their sons where fees are higher than are demanded at government schools. And even were it so, the well-known poverty of India precludes it.

The net result is therefore that if a much larger proportion of Christians is to be employed, and if the men are available, the Christian supporters of missions must be prepared to make large sacrifices to enable it to be done.

But here a remedy may be suggested. Why carry on so many schools? Close half and draft the Christian staff into the remainder.

Suppose we adopt this heroic measure. Let us say nothing about pledges to Government and to non-Christian masters : to boys and parents who value the teaching of the Bible and the friendship of the missionaries : to other societies who might have entered this field which they thought occupied : to supporters and contributors who believed in the schools and gave and worked and prayed for them. What will be the result ? Taking finance first, we lose the fees and the government grants in the closed schools and we have only the mission grant to transfer. Let us suppose that this small increase of income will pay the difference between the salaries of the non-Christian masters who have been dismissed and the Christian masters who are to be transferred : after all this sacrifice it is by no means certain that all the Christian staff of the old school would at once transfer themselves to another institution. Almost more than any race the Indian loves his home, and quickly gets restless and discontented, and often really ill, when his employment takes him far away. How many, again, would there be who would be tied by family, by property, by friendship to the old place and would simply take up some other work on the spot? The net result would be that we should diminish our schools by perhaps two-thirds, and that the surviving third would still have non-Christians on their staff : and the loss in influence and prestige with the people and with Government those who know India may imagine for themselves. 
Let us now consider the problem constructively. Handicapped as we admittedly are, what amount of good are we able to effect? Listen to a well-known quotation from a non-Christian paper :"With the cessation of their efforts in the direction of education their chances of gaining converts would become scarcer. It is the educational department with which is associated the memory of the most splendid achievements in proselytization: it is their department which has most markedly contributed to swell the ranks of converts." If this " unfriendly" testimony be accepted, to what shall we attribute the "splendid achievements"?

Primarily no doubt to the direct and regular simple Bible teaching in class and in Sunday school. The opposition of Hinduism in the school will nearly always be purely passive, a negative force. There is a positive force in the Christian atmosphere. When the whole system of the institution is Christian, when the Bible is taught daily in all the classes, when there is opening and closing prayer, when the whole ideal of life presented to the boys is Christian, we have a really bracing atmosphere. Obviously this atmosphere would be healthier if there were no non-Christians on the staff, but it is a mistake to suppose that the production of this atmosphere varies automatically with the number of non-Christians. I am not unaware that this laudation of the Christian atmosphere may be overdone. It may be overcome by the dead-weight of numbers, and it is important that schools should not get too large. But there can be no mechanical rule of thumb: so many pupils, so many Christian masters. This atmosphere must be personal, aggressive, individual. It is the personality of the individual which produces the atmosphere : I could quote instances where the life of one man has produced a stronger Christian influence in one school than the presence of half a dozen men of ordinary calibre has produced in another. Dr. Duff is a case in point. Look at the splendid results he achieved single-handed: and his pupils spread themselves all over India and laid the foundations of Christian education in other provinces.

This fact points to the need for care in the selection of Christian masters, rather than to an indiscriminate insistence on their number, without due regard to their special gifts. It is here that the presence of "short service men"-graduates from home universities, who join the staff of our mission schools and colleges on a short agreement before settling down to their life's work, has proved such an in- 
estimable boon. They are not "official" in the sense that the ordinary missionary is (any one who has worked in a mission school will know what I mean); they are known to have come on a nominal pay; they take their place with the Indian staff ; they are always welcomed and their presence does more to create the atmosphere required than almost anything else. Financially they help to solve the problems mentioned above, but their ignorance of the vernacular and consequent limitations in the subjects they are able to teach prevent their enlistment from being a solution of all our problems.

Secondly, we must not forget the influence of the Christian school on the non-Christian master himself. There are several cases of masters who have become Christian owing to the influence of the school. I know very few cases where the non-Christian master has been strong enough to carry on anything like an active campaign against the Christian teaching of the school : and it must be the principal's duty to see that such men are weeded out from the staff. The men who take employment are not infrequently those who have been educated in mission schools themselves, and they are able faithfully to carry on the traditions. One of the most famous mission schools (that at Srinagar) is practically staffed entirely with old non-Christian pupils, and their loyalty to the school traditions and the splendid work they have been able to effect are well known throughout India. In fact it may sometimes even be the case that a man who can carry on his boyhood's traditions in this way, albeit not a baptized Christian, may be more of a help in the school "team" than a man who, though baptized, has totally different ideals, or worse still, no ideals at all for educating boys.

The work of Christian education, carried on now for nearly a century, has not failed to permeate the life and thought of many a so-called non-Christian and not a few of these men are to be found on the staff of our mission schools.

Lastly, if mission schools are to be judged, let them be judged by their results. What have they achieved? It was stated not long ago by a missionary of half a century's experience that practically all the educated converts he had met had received their first impressions of Christianity at mission schools. And this is the testimony of not one but many famous students of missions as well as the everyday experience of missionaries in their stations.

Again the character of the mission school boy has been vindicated 
over and over again-more honest, more reliable, more straightforward than others. It has been remarked not only by Christians but by non-Christians that character is produced at Christian schools which is not produced by a purely secular education. It is the aggregate character of the mission school "old boys" which has permeated India and produced the wonderful change in the religious outlook of India which we are witnessing to-day.

We must all regret that it is rare to find in the north of India half the staff of a high school Christian, but befo:e sitting down to condemn the system wholesale, we have to consider the results achieved. I think we ought rather to praise God that, though the slackness and apathy of Christians have so cramped the work of Christian education, yet still He has achieved so much through such imperfect means.

Let us frankly acknowledge, however, that the means are imperfect; that a staff of which only one-third or one quarter is Christian is not ideal ; that though we are effecting something, and that that something is far too valuable to fling away, yet still we must not štt down content with this meagre success.

What is to be our policy?

First of all we must lose no opportunity of strengthening the Christian staff of our schools. As occasion offers we must add Christians to the staff Whenever a vacancy occurs we must really endeavour to find a Christian to fill it. This can be done up to a certain point, as $\mathrm{I}$ know from experience. We shall in time alter the proportion in our schools. But we must not sacrifice efficiency. Masterships must not become sinecures for inefficient Christians in order to please an ignorant outcry at home. There are good strong men, yet unbaptized, who are saturated with Christian teaching and whose outlook is Christian, and there are also baptized men, without force of character, who would simply be a drag on any institution. The Christians on the staff must be the best members of it or they have no right to be there.

This will mean some thought on the part of mission boards and committees. The finance must be thought out, for one thing, and except in special cases they should make up their minds to strengthen existing institutions rather than to open fresh schools and colleges. But it is not cnly a problem of finance.

There is also the training of Christian masters. No serious attempt, so far as I am aware, is being made in Upper India (I am not 
speaking of Bengal, where it is being well done) to train Christians as masters. All those who are trained go of their own initiative to the government training school or college. In a few cases a principal of a mission institution has been known to arrange for it, but otherwise the profession is left to any one who cares to go in for it and there are few who after taking their degree care to spend two years in further training, even though it involves little expense, when they might obtain a good post immediately with possibly a pension in reversion. What is needed is concerted action on the part of missionary societies to train Christian masters at an institution where they would have the advantages of Christian influence, together with the best modern scientific training. A hostel in connection with a government training college might meet the need ; or at any rate a system of scholarships which would supplement those already given by the Government.

Another important factor is the question of prospects for the Christian master. There are very few Indian managers of mission schools, or Indian principals of colleges. The career is at present one in which the Indian cannot hope to reach the top of the tree. Until we open it to legitimate ambition we shall never attract many of the best men from other professions to mission schools.

Meanwhile the employment of British or American graduates on "short service" will help to leaven the staff in secondary schools and colleges. And this method must be continued and extended. For primary and village schools the need for trained Christians has been much accentuated by the recent decision to extend primary education, and it is absolutely vital that missions should take the question of training in hand seriously. If under such a scheme as that proposed by Mr. A. G. Fraser of Kandy, union training colleges could be started in various centres in other parts of India, and the village schoolmasters prepared not only for the school but for village life with all its possibilities, the problem would be solved. But it must be done quickly or the opportunity will be lost.

Another most important means of correcting the evil of a partially non-Christian staff and one which has not always been properly taken into account, is the influence of the hostel and boarding-house. Where there is an efficient boarding-house staffed by Christians, the influence of the non-Christian class master is largely neutralised. The force of the home which is thus brought to bear is at least as great as that of the school. It must be, as it is already in a measure, 
the policy of our missionary societies to open boarding-houses and hostels in connection with all our schools and to appoint our strongest Christians to the oversight of them.

Lastly, the missions must jealously retain the right of appointing their own masters in aided institutions. It does sometimes happen that the Department tries to control all education. But the right to appoint our own masters and professors must be retained at all costs. It is not probable, hardly is it possible, in the face of government promises to aided education, that the contest could ever become so serious as to mean the loss of the grant. But should that evil day ever arise, we must be prepared to sacrifice all to keep the appointment of our masters in our own hands.

It will be noticed that in the above pages nothing has been said about female education. The reason is that non-Christian educated women are so few that the difficulty has not been whether we should staff Christian institutions with non-Christian women but how to staff secular institutions without Christian teachers. And with the challenge which that fact gives us and the bright outlook it opens to our eyes we may leave the subject. 